\title{
AKTYWIZACJA ZAWODOWA OPIEKUNÓW OSÓB Z NIEPEŁNOSPRAWNOŚCIAMI JAKO WAŻNE ZADANIE PAŃSTWA - WYBRANE ZAGADNIENIA
}

\author{
Abstract \\ Professional activation of guardians of disabled people as an important task \\ of the state - selected issues
}

It is beyond any doubt that the possibility of professional activation ensures not only the fulfillment of one's financial needs, but, above all, it allows an individual to be in charge of their life. The latter issue seems to be particularly important as far as the situation of guardians of people with disabilities is concerned, for everyone needs to have an influence upon their lives and the possibility to decide on the direction they want to move towards, regardless of the necessity to fulfill certain obligations in relation to other people. Pointing out particular solutions advocated by guardians of disabled people that support their professional activation and comparing them with the existing normative regulations, the author attempts to answer the question whether it is possible for a contemporary guardian of a disabled person to work professionally, without limiting oneself to performing care-service activities only.

Słowa kluczowe: opiekun osoby z niepełnosprawnością, aktywizacja zawodowa, praca, prace społecznie użyteczne

Keywords: guardian of disabled person, professional activation, job, socially useful jobs

ASJC: 3308, JEL: K31

\section{Zagadnienia wprowadzające}

Jednym z najistotniejszych warunków funkcjonowania człowieka jest możliwość podejmowania przez niego pracy zawodowej. Prawo do pracy jest zatem jednym z najważniejszych praw socjalnych gwarantujących jednostce minimum bezpieczeństwa ekonomicznego, bez którego nie byłaby ona w stanie dochodzić swych praw w sposób godny (Romer 1998). Jako prawo socjalne różni się ono od innych kategorii praw człowieka przede wszystkim tym, że upoważnia jednostkę do tego, aby domagała się ona 
od państwa pewnych dóbr i usług, które inni zdobywają dzięki własnej pracy lub na drodze wymiany rynkowej (Borski 2012, s. 15).

Nie ulega wątpliwości, że możliwość zawodowej aktywizacji nie tylko zapewnia realizację potrzeb finansowych, ale przede wszystkim pozwala na wzięcie odpowiedzialności za swój los. Ta ostatnia kwestia wydaje się szczególnie istotna dla opiekunów osób z niepełnosprawnościami, ponieważ każdy człowiek musi mieć wpływ na swoje życie i decydować o kierunku, w którym ma ono zmierzać, niezależnie od zobowiązań względem innych osób. Trzeba pamiętać, że realizacja obowiązków względem osób słabszych, pokrzywdzonych przez los, chociaż niewątpliwie ważna, nie powinna uniemożliwiać zaspokojenia potrzeb opiekunów. Poczucie wspólnoty, potrzeba zintensyfikowania swojej podmiotowości, realizacja celów, podnoszenie kwalifikacji i odnoszenie sukcesów są realizowane między innymi przez pracę (Borski 2018, s. 100 i n.).

Warto w tym miejscu zauważyć, że wśród opiekunów osób z niepełnosprawnościami istotną grupę stanowią osoby, które próbują godzić pracę z opieką nad osobą z niepełnosprawnością (Niedźwiedzka, Wisła 2016). Co prawda, statystycznie dochód $\mathrm{w}$ tych rodzinach jest wyższy $\mathrm{z}$ uwagi na dochód $\mathrm{z}$ pracy opiekuna, jednak nie można zapominać, że rodziny te ponoszą często dodatkowe koszty w związku z zapewnieniem opieki swoim bliskim na czas własnej nieobecności. Nie ulega zatem wątpliwości, że rodzinie $\mathrm{z}$ osobą z niepełnosprawnością bardzo potrzebne jest wsparcie nie tylko pieniężne (które w obecnym stanie prawnym i tak jest stanowczo niewystarczające), ale też w formie usług ${ }^{1}$, a także regulacji składających się na tzw. work-care balance ${ }^{2}$. Trzeba przy tym pamiętać, że państwo nie powinno w procesie wspierania koncentrować się wyłącznie na rodzicach i opiekunach całkowicie rezygnujących z pracy, takie podejście rodzi bowiem szereg negatywnych konsekwencji. Po pierwsze, pomija się doświadczenia dużej, również potrzebującej pomocy grupy. Po drugie, tworzone są instytucjonalne bodźce do dokonywania określonych wyborów życiowych w obliczu niepełnosprawności bliskich, które nie zawsze są optymalne ani dla poszczególnych członków rodziny z osobą z niepełnosprawnością, ani dla jej szerszego otoczenia. Wynika to $\mathrm{z}$ faktu, że rozwijając system wsparcia dla rezygnujących z pracy opiekunów, przy niedoborze wsparcia dla tych pracujących, państwo sprawia, że coraz więcej osób przechodzi z rynku pracy na system świadczeń opiekuńczych. Jak słusznie zauważa Rafał Bakalarczyk, dotyczy to zwłaszcza osób mających w swoim otoczeniu osobę wymagającą stałej opieki i jednocześnie wykonujących dotąd pracę mało stabilną, słabo wynagradzaną czy mało prestiżową (Bakalarczyk 2015, s. 70). Takie działania organów państwa mogą powodować w przyszłości powiększanie skali dezaktywizacji zawodowej, a także prowadzić do zwiększenia kręgu ubiegających się o świadczenia, co

1 Będą to np. usługi dostarczające informacji, doradcze, szkoleniowe i terapeutyczne, a także tzw. opieka wytchnieniowa czy inna forma bezpośredniego wsparcia opiekuna.

2 Chodzi o zapewnienie odpowiedniej równowagi między aktywnością zawodową a opieką długoterminową. Na temat instrumentów wsparcia opiekuna osoby starszej na rynku pracy w celu zachowania przedmiotowej równowagi zob. Furmańska-Maruszak 2015, s. 111-126. 
z kolei skutkować może generowaniem dodatkowych kosztów. Te zaś mogą oznaczać zmniejszanie wysokości świadczeń, a nawet ograniczanie dostępu do nich.

Tego typu działania niosą też za sobą koszty natury psychologicznej. Rafał Bakalarczyk zwraca w związku z tym uwagę, że:

System wsparcia opiekuna pod warunkiem pełnego oddania się opiece przez osobę bliską sprzyja wysokiemu poziomowi intensywności opieki, co często trwale wyklucza oddające się tej roli osoby (najczęściej jest to kobieta) z rynku pracy. Rodzi to też ryzyko społecznej izolacji i fizycznego oraz psychicznego wypalenia po stronie opiekuna, a po stronie podopiecznego ryzyko ograniczenia kontaktu z szerszym otoczeniem i tym samym utraty szans na pełną integrację (Bakalarczyk 2015, s. 70-71).

\section{Czy świadczenie pracy musi zawsze wykluczać pobieranie świadczenia pielęgnacyjnego?}

W kompleksowym programie wsparcia dla rodzin „Za życiem”3 przewidziano szereg postulowanych od dawna przez organizacje reprezentujące interesy środowiska opiekunów osób z niepełnosprawnościami rozwiązań, których celem jest doprowadzenie do aktywizacji zawodowej opiekunów osób z niepełnosprawnościami. Warto wskazać w tym miejscu na rozwiązanie pozwalające pracownikowi, który będzie rodzicem (lub jego małżonkowi), w razie ciąży z powikłaniami na złożenie pracodawcy wniosku o objęcie go indywidualnym rozkładem czasu pracy, ruchomym czasem pracy lub systemem przerywanego czasu pracy ${ }^{4}, c z y$ też rozszerzenie uprawnień urlopowych a także dostęp

3 Program kompleksowego wsparcia dla rodzin „Za życiem” przygotowany został przez międzyresortowy zespół, powołany przez premier Beatę Szydło. Program jest rozwinięciem i uzupełnieniem działań podjętych w ramach kontrowersyjnej ustawy z dn. 4 listopada 2016 r. o wsparciu kobiet w ciąży i rodzin „Za życiem” (Dz.U. 2019, poz. 473 tekst jedn.), dotyczącej wsparcia kobiet w ciąży powikłanej i rodzin w obliczu urodzenia się dziecka, u którego „zdiagnozowano ciężkie i nieodwracalne upośledzenie albo nieuleczalną chorobę" zagrażającą jego życiu. Program ten Rada Ministrów uchwaliła 20 grudnia 2016 r., a 30 grudnia uchwałę Rady Ministrów wraz z 110-stronicowym dokumentem opublikowano w „Monitorze Polskim”. Uchwała weszła w życie dwa dni później, czyli 1 stycznia 2017 r., jednak na realizację wszystkich elementów programu trzeba jeszcze poczekać.

410 maja $2018 \mathrm{r}$. Sejm uchwalił ustawę o zmianie ustawy o rehabilitacji zawodowej i społecznej oraz zatrudnianiu osób niepełnosprawnych oraz niektórych innych ustaw (Dz.U. 2018, poz. 1076), wprowadzającą zmiany m.in. do Kodeksu pracy (ustawa z dn. 26 czerwca 1974 r. - Kodeks pracy, Dz.U. 2018, poz. 917 tekst jedn. ze zm., dalej: „Kodeks pracy”, „k.p.”). Ustawa ta wprowadziła do Kodeksu pracy m.in. art. $142^{1} \S 1$, przewidujący możliwość skorzystania z elastycznych form organizacji czasu pracy (w przerywanym czasie pracy lub indywidualnym rozkładzie czasu pracy albo w ruchomym czasie pracy) na wiążący wniosek pracownika rodzica dziecka posiadającego zaświadczenie o ciężkim i nieodwracalnym upośledzeniu albo nieuleczalnej chorobie zagrażającej życiu, które powstały w prenatalnym okresie rozwoju dziecka lub w czasie porodu, oraz pracownika rodzica dziecka legitymującego się orzeczeniem o niepełnosprawności albo orzeczeniem o umiarkowanym lub znacznym stopniu niepełnosprawności oraz dziecka posiadającego odpowiednio: opinię o potrzebie wczesnego wspomagania rozwoju, orzeczenie o potrzebie kształcenia specjalnego lub orzeczenie o potrzebie zajęć rewalidacyjno-wychowawczych, a także 
do nieodpłatnego lub niskopłatnego wsparcia dziennego na czas, gdy opiekun wykonuje czynności zawodowe.

Od dłuższego już czasu w środowisku opiekunów osób z niepełnosprawnościami toczy się natomiast dyskusja na temat możliwości wykonywania dodatkowej pracy przez rodziców (opiekunów) sprawujących stałą opiekę nad osobami niepełnosprawnymi w stopniu znacznym i pobierających świadczenie pielęgnacyjne. Zdaniem części opiekunów, powinni oni mieć prawo do dodatkowej pracy. Jest to problem wywołujący ogromne kontrowersje w tym środowisku i bardzo je antagonizujący (Różański 2017).

Zgodnie $\mathrm{z}$ art. 17 ust. 1 ustawy $\mathrm{z}$ dn. 28 listopada 2003 r. o świadczeniach rodzinnych (Dz.U. 2018, poz. 2220 tekst jedn. ze zm.) świadczenie pielęgnacyjne przysługuje rodzicowi lub opiekunowi prawnemu lub faktycznemu bądź innym osobom, na których ciąży obowiązek alimentacyjny, rezygnującym z pracy zawodowej lub innej pracy zarobkowej w celu sprawowania stałej opieki nad osobą jej wymagającą. Wydaje się zatem, że świadczenie pielęgnacyjne ma być swego rodzaju rekompensatą za utracone zarobki przez sprawującego opiekę w wyniku rezygnacji z pracy zarobkowej ${ }^{5}$. Nie ma znaczenia, że jest to rezygnacja w pewnym stopniu wymuszona. Tak więc przyjęcie takiego toku rozumowania oznacza dla opiekuna osoby z niepełnosprawnością swego rodzaju alternatywę: albo jego podopieczny wymaga stałej opieki i tym samym uniemożliwia podjęcie przez rodzica (opiekuna) pracy, albo też ta sama osoba nie wymaga całodobowej opieki i wtedy rodzic może podjąć pracę zarobkową, tracąc jednak prawo do świadczenia pielęgnacyjnego.

pracownika małżonka albo pracownika rodzica dziecka w fazie prenatalnej, w przypadku ciąży powikłanej. W myśl art. $142^{1} \$ 2$ pracodawca może odmówić uwzględnienia takiego wniosku tylko wtedy, gdy byłoby to niemożliwe ze względu na organizację pracy lub jej rodzaj. Z kolei $₫ 3$ tego artykułu przewiduje, że z uprawnienia takiego mogą skorzystać także pracownicy opiekujący się dorosłymi dziećmi, tj. powyżej 18 roku życia. Poza tym nowelizacja ta przewidziała dodanie do art. $67^{6}$ k.p. $\$ 6-7$, przewidujących możliwość skorzystania z prawa do wykonywania pracy w formie telepracy na wiążący wniosek pracownika rodzica dziecka posiadającego zaświadczenie o ciężkim i nieodwracalnym upośledzeniu albo nieuleczalnej chorobie zagrażającej życiu, które powstały w prenatalnym okresie rozwoju dziecka lub w czasie porodu, oraz pracownika rodzica dziecka legitymującego się orzeczeniem o niepełnosprawności albo orzeczeniem o umiarkowanym lub znacznym stopniu niepełnosprawności oraz dziecka posiadającego odpowiednio: opinię o potrzebie wczesnego wspomagania rozwoju, orzeczenie o potrzebie kształcenia specjalnego lub orzeczenie o potrzebie zajęć rewalidacyjno-wychowawczych. Przyjęte rozwiązania przewidują m.in., że pracodawca nie może odmówić uwzględnienia wniosku, gdy przychylenie się do niego byłoby niemożliwe ze względu na organizację pracy lub rodzaj pracy wykonywanej przez pracownika. Z uprawnienia tego mogą skorzystać także pracownicy opiekujący się dorosłymi dziećmi, tj. powyżej 18 roku życia. Oprócz świadczenia pracy w wymienionej formie, na podstawie wniosku wiążącego pracodawcę, znowelizowany Kodeks pracy wprowadza w art. $67^{6} \$ 5$ możliwość wykonywania pracy w formie telepracy na ogólnych zasadach, na podstawie wniosku niewiążącego pracodawcę, niezależnie od zawarcia porozumienia określającego warunki stosowania telepracy z przedstawicielstwami pracowników.

5 Według Bożeny Kołaczek (2014, s. 23) z ekonomicznego punktu widzenia istotne staje się to, na ile poziom świadczenia może pełnić funkcję motywującą do bierności zawodowej innych dorosłych członków rodziny i stawać się głównym źródłem utrzymania. 
Czy rzeczywiście takie było ratio legis tego przepisu? Nie ulega wątpliwości, że dziecko z niepełnosprawnością w stopniu znacznym wymaga stałej opieki, nieporównalnie bardziej intensywnej niż w przypadku dziecka sprawnego. Nie we wszystkich przypadkach jednak opieka ta jest tak uciążliwa, by rodzic (opiekun) nie mógł podjąć dodatkowego zajęcia zarobkowego. Jest to możliwe zwłaszcza wtedy, gdy opiekę sprawuje oboje rodziców. Świadczenie pielęgnacyjne najczęściej nie jest przecież ekwiwalentem utraconych możliwych zarobków, dodatkowo ogranicza funkcjonowanie drugiego z rodziców, a to powoduje, że sytuacja materialna takiej rodziny staje się bardzo zła. Jak łatwo się domyślić, w przypadku osób samotnie sprawujących opiekę nad dziećmi z niepełnosprawnościami sytuacja ta jest znacznie gorsza. Środowiska opiekunów osób z niepełnosprawnościami od dłuższego już czasu postulują taką zmianę treści omawianego przepisu, aby świadczeniem pielęgnacyjnym objęci zostali rodzice (opiekunowie) rezygnujący z pracy zawodowej na pełnym etacie $\mathrm{z}$ uwagi na sprawowaną opiekę. Całkowita rezygnacja z życia zawodowego, a niekiedy ważnej kariery zawodowej jest dla opiekunów skrajnie niekorzystna, zatem powinno się, ich zdaniem, dopuścić łączenie pobierania świadczenia pielęgnacyjnego ze świadczeniem pracy w niepełnym wymiarze czasu pracy (Borski 2018, s. 104).

Warto w tym miejscu odwołać się do tzw. piramidy Maslowa, która ukazuje, jak ewoluują potrzeby człowieka w miarę jego rozwoju i wieku'. Pierwszą grupą są tzw. potrzeby fizjologiczne, obejmujące pożywienie, mieszkanie, odzież i prokreację, po których wymieniane są potrzeby bezpieczeństwa, w postaci zabezpieczenia przed chorobą i bezrobociem, a następnie przynależności (potrzeby akceptacji, miłości, przyjaźni, przynależności do grupy). Można powiedzieć, że na tym poziomie opiekunowie osób z niepełnosprawnościami się zatrzymują, gdyż brak możliwości świadczenia dodatkowej pracy, której podjęcie nie oznaczałoby utraty świadczeń, powoduje, ze opiekun mający często dobry zawód i swoje pasje nie może w żaden sposób się rozwijać, w wyniku czego zaprzepaszcza swoje wykształcenie oraz umiejętności na rzecz opieki i bezgranicznego oddania się osobie z niepełnosprawnością. W ten sposób jego potrzeby uznania (szacunku, sukcesu, prestiżu i znaczenia), a także samorealizacji (rozwijania swoich zdolności, zainteresowań i sfery duchowej) pozostają niezaspokojone. Aby zaspokoić te potrzeby, opiekun musi postąpić nieuczciwie, czyli pracować „na czarno” i oszukiwać państwo, nie odprowadzając podatków i składek. Legalne zatrudnienie u określonego pracodawcy spowoduje bowiem, że pozbawi on swoje dziecko z niepełnosprawnością przysługującej mu niezbędnej opieki (Borski 2018, s. 104).

Warto w tym miejscu podkreślić, że zdecydowana większość środowiska opiekunów osób z niepełnosprawnościami chciałaby mieć zagwarantowane prawo do

6 Abraham Maslow opisał własną teorię psychologiczną, tzw. hierarchię potrzeb, w roku 1943, w artykule The Theory of Human Motivation, w naukowym czasopiśmie „Psychological Review”. Założył on, że ludzkie potrzeby są zaspokajane stopniowo. Innymi słowy, człowiek stawia przed sobą większe cele i ma większe aspiracje, jeśli zaspokoi najpierw swoje podstawowe pragnienia. 
wykonywania dodatkowej pracy przy jednoczesnym zachowaniu prawa do pobierania świadczenia pielęgnacyjnego ${ }^{7}$. Opiekunowie słusznie twierdzą, że nie mogą podejmować stałej pracy etatowej, byłoby to bowiem nie do pogodzenia $\mathrm{z}$ opieką nad dzieckiem $z$ niepełnosprawnością. Nic jednak nie stoi na przeszkodzie, żeby podjęli pracę dodatkową, dorywczą. Przecież nie zawsze sprawowana opieka jest tak wyczerpująca, by rodzic nie mógł podjąć dodatkowej pracy w niepełnym wymiarze czy też korzystać z różnorodnych elastycznych form zatrudnienia. Taka dodatkowa praca może być przecież wykonywana praktycznie wszędzie, o każdej porze dnia i nocy. W ciągu dnia dziecko uczestniczy najczęściej w wielu zajęciach szkolnych lub rewalidacyjnych, a nawet gdy jest $\mathrm{w}$ domu, pogodzenie obowiązków wynikających ze świadczenia pracy z opieką nie zawsze musi stanowić problem. Nie ulega wątpliwości, że dodatkowa praca nie musi pogarszać jakości sprawowanej opieki, tym bardziej że zazwyczaj dziecko z niepełnosprawnością posiada oboje rodziców, którzy mogą swoje obowiązki tak zorganizować, żeby mieć czas na dodatkową pracę. Bardzo ważne jest jednak, aby od wszystkich dodatkowych dochodów były odprowadzane wymagane świadczenia, bo tylko w ten sposób opiekun jest w stanie wykazać się niezbędnym doświadczeniem, stażem.

Warto zwrócić uwagę na jeszcze jeden argument przemawiający za dopuszczalnością dodatkowej pracy. Otóż taka praktyka uzyskiwania dodatkowych dochodów i tak ma miejsce, tyle tylko że odbywa się to w ramach tzw. szarej strefy.

Niezależnie od argumentów finansowych ważne wydają się korzyści natury psychologicznej. Dla wielu rodziców (opiekunów) osób z niepełnosprawnościami dodatkowa praca może stanowić także pewien rodzaj autoterapii (Jużyczyński 2017). Co więcej, jej podjęcie może oznaczać dla nich nadzieję utrzymania ciągłości aktywności zawodowej. Niestety, często zdarza się, że dziecko po kilkudziesięciu latach umiera, a rodzic przeżywa podwójną rozpacz. $Z$ jednej strony jest to trauma po utracie ukochanej osoby, z drugiej całkowita bezradność zawodowa. Warto też nadmienić, że opiekun jest zazwyczaj poddany znacznym obciążeniom i zagrożeniom psychicznym, zwykle nasilającym się w terminalnej fazie życia podopiecznego. Jak słusznie zauważa Rafał Bakalarczyk, okres następujący bezpośrednio po ustaniu opieki ze względu na śmierć bliskiej osoby nie jest czasem, w którym łatwo jest wrócić na rynek pracy, zwłaszcza po latach zawodowej dezaktywizacji. Dlatego też za w pełni uzasadnione należy uznać przynajmniej czasowe wsparcie w formie zasiłku, zabezpieczające dochód byłego opiekuna do czasu powrotu na rynek pracy lub osiągnięcia uprawnień emerytalnych (Bakalarczyk 2016, s. 61).

7 Postulat ten wspiera organizacja pozarządowa - Instytut Spraw Obywatelskich (INSPRO), która przeprowadziła kampanię promocyjną „Dom to praca”, dzięki której udało jej się zebrać 20 tysięcy podpisów pod petycją „Zmień prawo. Pozwól opiekunom dorabiać”. Petycję tę wsparła także małżonka prezydenta RP Agata Kornhauser-Duda. 


\section{Opieka wyręczająca jako instrument wspierający aktywizację zawodową opiekunów osób z niepełnosprawnościami i osób bezrobotnych}

Postulowane przez środowiska opiekunów osób z niepełnosprawnościami rozwiązanie pozwalające na podejmowanie przez nich dodatkowej pracy bez konieczności rezygnacji ze świadczenia pielęgnacyjnego do dziś nie doczekało się odpowiednich regulacji normatywnych. Niezależnie od tego środowisko to jest stosunkowo często inicjatorem zmian w systemie powszechnie obowiązującego prawa mających na celu zwiększenie ich aktywności zawodowej.

Jednym z wielu sposobów aktywizowania opiekunów osób z niepełnosprawnościami jest tzw. opieka wyręczająca, polegająca na wykonywaniu prac związanych z realizacją codziennych obowiązków domowych na rzecz opiekunów osób z niepełnosprawnościami w ramach prac społecznie użytecznych. To rozwiązanie - z powodzeniem funkcjonujące w innych państwach, nie tylko w krajach skandynawskich, ale też na przykład w bliskiej nam Republice Czeskiej - zakłada odciążanie opiekunów osób z niepełnosprawnościami od wielu obowiązków domowych, takich jak sprzątanie, zakupy, załatwianie spraw urzędowych itp. Dzięki temu opiekun może skupić się na czynnościach opiekuńczo-pielęgnacyjnych w stosunku do swego podopiecznego. Ma także więcej czasu na realizację własnego hobby, świadczenie dodatkowej pracy (oczywiście jeżeli nie pobiera świadczenia pielęgnacyjnego) lub na odpoczynek. W Polsce ten bardzo ciekawy środek aktywizujący o dwustronnym charakterze (oprócz potencjalnej aktywizacji zawodowej opiekuna zakłada aktywizację zawodową osoby bezrobotnej, która świadczy pracę na rzecz opiekuna osoby z niepełnosprawnościami) wprowadzony został z dn. 1 lipca 2017 r. przez ustawę z dn. 22 czerwca 2017 r. o zmianie niektórych ustaw w związku z realizacją programu „Za życiem” (Dz.U. 2017 poz. 1292; art. 73a ust. 5b znowelizowanej przez nią ustawy z dn. 20 kwietnia 2004 r. o promocji zatrudnienia i instytucjach rynku pracy, Dz.U. 2018, poz. 1265 tekst jedn. ze zm., dalej: „ustawa o promocji zatrudnienia i instytucjach rynku pracy). Ustawa ta znowelizowała między innymi ustawę o promocji zatrudnienia i instytucjach rynku pracy, której art. 73a ust. 5b stanowi, że starosta refunduje gminie ze środków Funduszu Pracy do 100\% minimalnej kwoty świadczenia przysługującego bezrobotnemu bez prawa do zasiłku ${ }^{8}$ oraz osobie uczestniczącej w kontrakcie socjalnym, indywidualnym programie usamodzielnienia, lokalnym programie pomocy społecznej lub indywidualnym programie zatrudnienia socjalnego skierowanym do wykonania prac związanych z realizacją codziennych obowiązków domowych na rzecz opiekunów osób z niepełnosprawnościami. W sposób szczegółowy kwestie związane ze sposobem

8 Powinny to być osoby, dla których ustalono II profil pomocy. Profil ten ustalany jest dla osób wymagających intensywnego wsparcia ze strony PUP w celu znalezienia zatrudnienia. Realizacja indywidualnego planu działania, którego realizacja powinna doprowadzić do podjęcia pracy, nie powinna przekroczyć w tym profilu 540 dni. Osoba taka w ramach realizacji planu może korzystać m.in. z pomocy z zakresu pośrednictwa pracy, poradnictwa zawodowego, szkoleń, pożyczek i dofinansowań. 
i trybem organizowania prac społecznie użytecznych, w tym warunki ustalania świadczenia za wykonywanie tych prac, określa rozporządzenie Ministra Rodziny, Pracy i Polityki Społecznej z dn. 21 grudnia 2017 r. w sprawie organizowania prac społecznie użytecznych (Dz.U. 2017, poz. 2447; dalej: „rozporządzenie MRPiPS z dn. 21 grudnia 2017 r."). Warto w tym miejscu zauważyć, że pod pojęciem prac społecznie użytecznych należy rozumieć prace wykonywane przez osoby wskazane $\mathrm{w}$ art. 73a ust. 5b ustawy o promocji zatrudnienia i instytucjach rynku pracy, na skutek skierowania przez powiatowy urząd pracy (dalej: „PUP”), organizowane przez gminę w jednostkach organizacyjnych pomocy społecznej, w tym również na rzecz opiekunów osób z niepełnosprawnościami, w organizacjach lub instytucjach statutowo zajmujących się pomocą charytatywną lub na rzecz społeczności lokalnej.

Biorąc powyższe pod uwagę, wydaje się, że kluczowymi podmiotami realizującymi wsparcie tego rodzaju dla opiekunów osób z niepełnosprawnościami i osób bezrobotnych są: starosta powiatu działający za pośrednictwem dyrektora PUP, będącego częścią powiatowej administracji zespolonej, oraz gmina jako podmiot organizujący te prace, oczywiście za pośrednictwem właściwego ośrodka pomocy społecznej (Borski 2018, s. 160).

PUP kieruje osobę do wykonywania prac społecznie użytecznych na rzecz opiekuna osoby z niepełnosprawnością po uzyskaniu od właściwej gminy informacji na temat potrzeb w tym zakresie. Właśnie dlatego gmina sporządza do dn. 31 stycznia każdego roku roczny plan potrzeb w zakresie wykonywania prac społecznie użytecznych i przesyła go właściwemu miejscowo staroście i kierownikowi ośrodka pomocy społecznej. Plan ten musi zawierać określone elementy wskazane w $\$ 2$ ust. 2 rozporządzenia MRPiPS $\mathrm{z}$ dn. 21 grudnia $2017 \mathrm{r}$. $^{9}$

Szczegółowe zasady i tryb postępowania w sprawach dotyczących organizacji prac społecznie użytecznych na rzecz opiekunów osób z niepełnosprawnościami, z uwzględnieniem gminnego planu potrzeb, określa porozumienie zawarte pomiędzy PUP a gminą. Nie wchodząc w szczegóły, to porozumienie powinno określać między innymi zakres codziennych obowiązków domowych wykonywanych w ramach prac na rzecz opiekunów osób z niepełnosprawnościami, a w szczególności prace o charakterze pomocniczym, z wyłączeniem prac związanych z bezpośrednią opieką nad osobą z niepełnosprawnością, zwłaszcza pielęgnacji tych osób, zabiegów higienicznych i podawania leków. Ponadto w porozumieniu powinno znaleźć się określenie wysokości i terminów refundowania przez starostę z Funduszu Pracy świadczeń wypłacanych osobom uprawnionym z tytułu wykonywania prac społecznie użytecznych.

9 Zgodnie $\mathrm{z}$ tym przepisem plan powinien obejmować: 1. rodzaje prac społecznie użytecznych; 2. liczbę godzin wykonywania prac społecznie użytecznych; 3 . liczbę bezrobotnych bez prawa do zasiłku korzystających ze świadczeń pomocy społecznej oraz liczbę osób uczestniczących w kontrakcie socjalnym, indywidualnym programie usamodzielnienia, lokalnym programie pomocy społecznej lub indywidualnym programie zatrudnienia socjalnego, jeżeli podjęly uczestnictwo w tych formach w wyniku skierowania PUP na podstawie art. 50 ust. 2 ustawy o promocji zatrudnienia i instytucjach rynku pracy, które mogą być skierowane do wykonywania prac społecznie użytecznych. 
Na podstawie zawartego porozumienia kierownik właściwego ośrodka pomocy społecznej sporządza listę osób uprawnionych, które mogą być skierowane do wykonywania prac społecznie użytecznych związanych z realizacją codziennych obowiązków domowych na rzecz opiekunów osób z niepełnosprawnościami i przesyła ją do właściwego miejscowo PUP. Warto podkreślić, że lista ta jest sporządzana przez kierownika ośrodka pomocy społecznej według terminów wynikających z przygotowanego wcześniej przez gminę rocznego planu potrzeb, co oznacza, że powinna ona być aktualna w momencie kierowania przez PUP osób bezrobotnych do wykonywania prac społecznie użytecznych.

Dopiero wtedy, po zweryfikowaniu listy, dyrektor PUP wydaje osobie uprawnionej skierowanie do prac społecznie użytecznych, na podstawie wcześniejszego skierowania z właściwego ośrodka pomocy społecznej i zgodnie ze zgłoszeniem wolnego miejsca. Warto w tym miejscu zauważyć, że osoba ta zachowuje status osoby bezrobotnej w trakcie wykonywania tych prac i między nią a ośrodkiem pomocy społecznej (który w dalszej kolejności wskaże jej zakres obowiązków wykonywanych na rzecz konkretnego opiekuna osoby z niepełnosprawnością) nie jest zawierana żadna umowa ani nie nawiązuje się stosunku pracy (Borski 2018, s. 161). Podjęcie decyzji o skierowaniu osoby bezrobotnej do wykonywania tych prac powinno być poprzedzone analizą pod kątem jej zgodności z zasadą racjonalności gospodarowania środkami Funduszu Pracy. PUP powinien zatem zbadać, czy jest to optymalna forma pomocy dla konkretnej osoby.

Powyższe rozważania pozwalają na sformułowanie wniosku, że między gminą a osobą kierowaną do wykonywania prac społecznie użytecznych na rzecz opiekuna osoby $\mathrm{z}$ niepełnosprawnością powstaje relacja o charakterze zobowiązaniowym. Obie strony mają zatem wobec siebie zobowiązania wyrażające się między innymi:

1) ze strony gminy w zobowiązaniu do:

- stworzenia bezpiecznych i higienicznych warunków wykonywania pracy społecznie użytecznej,

- uwzględnienia przy przydziale prac społecznie użytecznych wieku bezrobotnego, stanu jego zdrowia oraz - w miarę możliwości - posiadanych kwalifikacji,

- pouczenia osoby bezrobotnej o konieczności przestrzegania ustalonego w miejscu wykonywania pracy społecznie użytecznej porządku i dyscypliny,

- zapoznania bezrobotnego z przepisami dotyczącymi bezpieczeństwa i higieny pracy,

- ustalenia wysokości przysługującego bezrobotnemu świadczenia (z uwzględnieniem rodzaju i efektów wykonywanej pracy) oraz do wypłaty tego świadczenia pieniężnego $\mathrm{w}$ okresach miesięcznych $\mathrm{z}$ dołu;

2) po stronie osoby bezrobotnej, bez prawa do zasiłku i korzystającej ze świadczeń pomocy społecznej, w zobowiązaniu do:

- wykonywania prac społecznie użytecznych w miejscu, czasie i w sposób wskazany przez gminę oraz opiekuna osoby z niepełnosprawnością,

- przestrzegania ustalonego w miejscu wykonywania pracy społecznie użytecznej porządku, dyscypliny i zasad bezpieczeństwa. 
W tym miejscu warto zwrócić uwagę na aspekt finansowy szczegółowo przedstawionej wyżej formy wsparcia. Otóż osoby skierowane do pracy na rzecz opiekuna osoby z niepełnosprawnością mogą otrzymać wynagrodzenie w kwocie minimum $8,30 \mathrm{zł}$ za godzinę, przy czym wykonywanie tych prac może trwać maksymalnie 10 godzin tygodniowo. Zważywszy na fakt, że minimalna stawka godzinowa dla osób świadczących pracę na podstawie umowy zlecenia wynosi od roku 2019 14,70 zł, kwota 8,30 zł oferowana osobom bezrobotnym jest rażąco niska. Wydaje się, że ustawodawca przyjął a priori, że gminy będą elementem wsparcia procesów aktywizacji zawodowej, współfinansując zatrudnienie osób bezrobotnych świadczących prace na rzecz opiekunów osób z niepełnosprawnościami. W OSR projektu rozporządzenia MRPiPS z dn. 21 grudnia 2017 r. przyjęto, że grupa bezrobotnych bez prawa do zasiłku, która mogłaby skorzystać $\mathrm{z}$ tego instrumentu aktywizacji, wynosi niemal milion osób (918 372). Od tego czasu sytuacja na rynku pracy diametralnie się jednak zmieniła. Poziom bezrobocia jest dziś rekordowo niski ${ }^{10}$, co biorąc pod uwagę wskazaną wyżej kwotę wynagrodzenia, może oznaczać poważne problemy ze znalezieniem chętnych do tej pracy. Niezależnie od tego ustalenie stawki godzinowej za pracę na tak niskim poziomie byłoby obecnie sprzeczne $\mathrm{z}$ brzmieniem art. $8 \mathrm{a}$ ustawy $\mathrm{z}$ dn. 10 października 2002 r. o minimalnym wynagrodzeniu za pracę (Dz.U. 2018, poz. 2177 tekst jedn. ze zm.). Warto jednocześnie zauważyć, że zgodnie $z$ art. 73a ust. 5a ustawy o promocji zatrudnienia i instytucjach rynku pracy wynagrodzenie osoby świadczącej pracę na rzecz opiekuna osoby z niepełnosprawnością może być $\mathrm{w}$ całości finansowane $\mathrm{z}$ budżetu gminy. Oznacza to w praktyce, że gmina będzie wypłacać to wyższe wynagrodzenie, równe co najmniej 14,70 zł za godzinę, współfinansując $w$ ten sposób wykonywanie prac społecznie użytecznych na rzecz opiekunów osób z niepełnosprawnościami (Borski 2018, s. 162-163).

Oczywiście nie można zapominać, że ten instrument wsparcia dotyczy nie tylko pomocy opiekunom osób z niepełnosprawnościami w realizacji codziennych obowiązków domowych, ale też wszystkich prac zaliczanych do kategorii społecznie użytecznych, takich jak na przykład prace porządkowe czy też praca nad rzecz organizacji charytatywnej.

Realizacja przez gminę obowiązku wypłaty osobie bezrobotnej świadczenia pieniężnego z tytułu wykonywania prac społecznie użytecznych na rzecz opiekuna osoby $\mathrm{z}$ niepełnosprawnością następuje $\mathrm{w}$ okresach miesięcznych, $\mathrm{z}$ dołu. Warto przy tym podkreślić, że za wypłacone świadczenia otrzymuje ona pełną refundację (100\%) ze środków Funduszu Pracy (maksymalnie jednak do wysokości 8,30 zł za godzinę pracy). Podstawą do refundacji jest art. 73a ust. 5b ustawy o promocji zatrudnienia i instytucjach rynku pracy. Stosowny wniosek o refundację gmina składa do PUP. W przypadku miast na prawach powiatu ośrodki pomocy społecznej będące organizatorami wykonywania prac społecznie użytecznych na rzecz opiekunów osób z niepełnosprawnościami składają wniosek o refundację bezpośrednio do PUP. Należy zauważyć, że ani ustawa

10 Według danych Głównego Urzędu Statystycznego z końca stycznia 2019 r. stopa bezrobocia rejestrowanego wyniosła 6,1\%, a liczba wszystkich bezrobotnych (także tych bez prawa do zasiłku) nieznacznie przekroczyła milion (1023,1 tys.). Za: GUS 2019. 
o promocji zatrudnienia i instytucjach rynku pracy, ani rozporządzenie MRPiPS z dn. 21 grudnia 2017 r. nie określają żadnych terminów związanych z realizacją procedury refundacji. Kwestia ta jest precyzowana zwykle albo w porozumieniu zawieranym pomiędzy PUP a gminą, albo w odrębnym akcie prawa wewnętrznego tworzonym przez PUP (Powiatowy Urząd Pracy w Gliwicach, 2012). Uregulowanie tej kwestii jest szczególnie istotne, gdyż gmina, wypłacając świadczenie osobie wykonującej prace społecznie użyteczne na rzecz opiekuna osoby z niepełnosprawnością, musi najpierw wydatkować określoną kwotę i oczekiwać na jej refundację. Tak więc termin refundacji powinien być nieodległy, tak aby nie powodować komplikacji w zakresie gospodarki finansowej gminy.

Warto podkreślić, że $\$ 5$ ust. 3 rozporządzenia MRPiPS z dn. 21 grudnia 2017 r. nakłada na opiekuna osoby z niepełnosprawnością określone obowiązki informacyjne. Ma on obowiązek zawiadomienia gminy w przypadku gdy osoba, która miała wykonywać na jego rzecz prace społecznie użyteczne:

1) nie zgłosi się do ich wykonywania,

2) nie podjęła przydzielonej jej pracy,

3) opuściła miejsce wykonywania prac,

4) naruszyła porządek i dyscyplinę w miejscu wykonywania pracy.

Należy zauważyć, że przepisy prawa powszechnie obowiązującego nie przewidują wprost możliwości wyboru przez opiekuna osoby, która będzie świadczyła pracę na jego rzecz. W praktyce jednak okazuje się, że gminy same proponują opiekunom skorzystanie $\mathrm{z}$ tej możliwości i dokonanie wyboru odpowiedniej osoby. Osobą tą może być także bezrobotny członek rodziny opiekuna osoby z niepełnosprawnością. Wydaje się, że tego rodzaju rozwiązania można byłoby zaliczyć do tzw. dobrych praktyk, pomiędzy osobą świadczącą pracę a opiekunem powinna bowiem istnieć swego rodzaju nić porozumienia, umożliwiająca efektywne wykonywanie powierzonych zadań.

Podsumowując dotychczasowe rozważania, warto podjąć próbę ustalenia, kto może skorzystać z omówionej powyżej regulacji, czyli stać się jej beneficjentem, kto zaś ponosi koszty jej wprowadzenia do porządku prawnego. Wydaje się, że do kategorii beneficjentów prezentowanej tu regulacji zaliczyć można nie tylko osoby bezrobotne, które uzyskują wymierną korzyść finansową (choć jak była o tym mowa wyżej - stosunkowo niewielką), ale także gminy, w których interesie leży przecież aktywizowanie mieszkańców, a w konsekwencji zmniejszanie bezrobocia. Najważniejszym beneficjentem staje się jednak opiekun osoby z niepełnosprawnością, który dzięki tej formie wsparcia ma więcej czasu na realizację innych obowiązków związanych $\mathrm{z}$ bezpośrednią opieką nad osobą z niepełnosprawnością, na dodatkową pracę (jeśli nie pobiera na swego podopiecznego świadczenia pielęgnacyjnego), czasem może też zwyczajnie odpocząć, nie martwiąc się o codzienne zakupy czy też sprzątanie. $Z$ kolei koszty realizacji tzw. opieki wyręczającej ponoszą z jednej strony pracodawcy opłacający składki na Fundusz Pracy, z drugiej zaś budżet państwa, który może zasilać ten fundusz dotacjami. To właśnie ze środków funduszu w pełni pokrywane są bowiem wynagrodzenia osób bezrobotnych wykonujących prace społecznie użyteczne na rzecz opiekunów osób z niepełnosprawnościami. 
Na marginesie warto zauważyć, że od pewnego czasu pojawiały się propozycje obniżenia wysokości składki na Fundusz Pracy, wskazujące, że w ten sposób będzie można ulżyć pracodawcom i obniżyć bardzo wysokie w Polsce obciążenia przez nich ponoszone. Wydaje się, że potrzebne jest wręcz odwrotne działanie, idące w kierunku zwiększenia tej składki. Zważywszy na fakt, że obecnie należy ona do najniższych w Europie (średnio około 5,5\% wynagrodzenia), w miarę wzrostu zatrudnienia i wynagrodzeń powinno się również dążyć do zwiększenia funduszu, aby znacząco zmniejszyć bezrobocie, podnieść rangę polityki przeciwdziałania temu zjawisku i poprawić szanse na zatrudnienie.

Do grona podmiotów finansujących koszty opieki wyręczającej mogą też dołączyć te gminy, które częściowo sfinansują koszt wynagrodzenia osób bezrobotnych, refundowana kwota $8,30 \mathrm{zł}$ za godzinę została bowiem ustalona na wyjątkowo niskim poziomie i gmina, chcąc pozyskać osobę do wykonywania pracy na rzecz opiekuna osoby z niepełnosprawnością, będzie musiała w praktyce „dopłacić” do wysokości wskazanej już wcześniej kwoty 14,70 zł.

\section{Zamiast zakończenia}

Przedstawione wyżej rozważania skłaniają do głębszej refleksji i próby odpowiedzi na pytanie, czy i w jakim stopniu państwo polskie wspiera działania na rzecz aktywizacji zawodowej opiekunów osób z niepełnosprawnościami. Wydaje się, że wprowadzenie rozwiązań z zakresu tzw. opieki wyręczającej czy stworzenie opiekunom osób z niepełnosprawnościami warunków do podejmowania zatrudnienia przy zastosowaniu elastycznych form zatrudnienia czy organizacji czasu pracy pozwalają na optymistyczną konstatację, że przepisy te wspierają funkcjonalnie postulaty podnoszone od lat przez najbardziej zainteresowane środowiska opiekunów osób z niepełnosprawnościami. Oczywiście w dalszym ciągu jest bardzo wiele do zrobienia. Wiele z rozwiązań, które od lat przedstawiane są prawodawcy przez środowiska opiekunów osób z niepełnosprawnościami z różnych powodów, w tym często finansowych, do tej pory nie doczekało się realizacji.

Nie ulega wątpliwości, że tworzenie rozwiązań umożliwiających podejmowanie zatrudnienia przez opiekunów osób z niepełnosprawnościami jest niezwykle istotne, gdyż możliwość pracy zawodowej w życiu każdego człowieka jest jednym z najistotniejszych warunków funkcjonowania. Możliwość podejmowania aktywności zawodowej zapewnia nie tylko realizację potrzeb finansowych, ale przede wszystkim pozwala na wzięcie odpowiedzialności za swój los. Szczególnie ta ostatnia kwestia wydaje się mieć istotne znaczenie dla sytuacji opiekunów osób z niepełnosprawnościami, ponieważ każdy człowiek musi mieć wpływ na swoje życie i decydować o kierunku, w którym ma ono zmierzać, niezależnie od konieczności realizacji pewnych zobowiązań względem innych osób. Warto podkreślić, że wspieranie osób słabszych, pokrzywdzonych przez los, chociaż bardzo uzasadnione, nie może zupełnie zdominować zaspokajania własnych potrzeb przez opiekunów. Poczucie wspólnoty, potrzeba zintensyfikowania 
swojej podmiotowości, realizacja celów, podnoszenie kwalifikacji i odnoszenie sukcesów - wszystkie te cele są przecież realizowane między innymi przez pracę.

\section{Bibliografia}

Bakalarczyk R. (2015) Polityka wsparcia rodzin z osobami niepełnosprawnymi. W cieniu wyroków Trybunału Konstytucyjnego RP i protestów społecznych, „Studia z Polityki Publicznej”, nr 1.

Bakalarczyk R. (2016) Wybrane problemy zabezpieczenia społecznego osób opiekujących sie niesamodzielnymi bliskimi - wyzwania dla Sejmu VIII Kadencji, „Ubezpieczenia Społeczne. Teoria i praktyka”, nr 3.

Borski M. (2012) Prawo do pracy jako wartość uniwersalna [w:] B.M. Ćwiertniak (red.), Aktualne zagadnienia prawa pracy i polityki socjalnej (zbiór studiów), t. 1, Sosnowiec.

Borski M. (2018) Publiczne formy wspierania opiekunów osób z niepełnosprawnościami, Sosnowiec.

Furmańska-Maruszak A. (2015) Równowaga między pracq a opieką. Wsparcie nieformalnego opiekuna osoby starszej na rynku pracy w porównaniach międzynarodowych, „Acta Universitatis Lodziensis. Folia Oeconomica", nr 2(312).

GUS (2019) Informacja o liczbie bezrobotnych zarejestrowanych oraz stopa bezrobocia wedtug statystycznego podziału kraju (rewizja NUTS 2016) oraz administracyjnego podziału terytorialnego kraju (TERYT). Stan w końcu stycznia 2019 r., http://stat.gov.pl/obszary-tematyczne/ rynek-pracy/bezrobocie-rejestrowane/bezrobotni-zarejestrowani-i-stopa-bezrobocia-stan-w-koncu-stycznia-2019-r-,2,78.html (dostęp: 8.03.2019).

Jużyczyński J. (2017) Socjalne pasożytnictwo staje się sposobem na życie i polityką?, https:// bastiondialogu.pl/socjalne-pasozytnictwo (dostęp: 8.03.2019).

Kołaczek B. (2014) Świadczenia pielęgnacyjne dla opiekunów dzieci niepetnosprawnych - funkcje społeczne i ekonomiczne, „Polityka Społeczna”, nr 4.

Maslow, A.H. (1943) A Theory of Human Motivation, „Psychological Review”, vol. 50(4).

Niedźwiedzka A., Wisła I. (2016) Informator dla rodziców dzieci z niepełnosprawnościami „Jestem mamą. Nie rehabilitantka. Jestem Tatą. Nie terapeuta”, http://programwyspa.pl/sites/default/ files/informator_dla_rodzicow_jestem_mama._nie_rehabilitantka._jestem_tata._nie_terapeuta.pdf (dostęp: 3.01.2019).

Powiatowy Urząd Pracy w Gliwicach (2012) [Regulamin organizowania prac społecznie użytecznych], http://www.pup.gliwice.pl/pracodawcy_przedsiebiorcy/prace_spolecznie_uzyteczne. html (dostęp: 27.01.2019).

Romer M.T. (1998) Prawa socjalne, „Szkoła Praw Człowieka”, z. 5.

Różański M. (2017) Dorabianie rodziców do świadczeń. Za i przeciw, http://www.niepelnosprawni. pl/ledge/x/634160 (dostęp: 8.02.2019). 